\title{
Lesson learn earthquake disaster in Pidie Jaya Aceh in 2016 to realize a disaster-resistant community
}

\author{
Najib Rahman ${ }^{1 *}$,Heridadi ${ }^{1}$ Lasmono $^{1}$, Mulya Imansyah ${ }^{1}$, and Fauzi Bahar ${ }^{1}$ \\ ${ }^{1}$ Disaster Management Study Program, National Security Faculty, Republic of Indonesia Defense University. IPSC Sentul Area, \\ Bogor, West Java, Indonesia
}

\begin{abstract}
Indirectly, to protect and achieve prosperity, national security is needed as the freedom for the state, society, and citizens from all the threats. Natural disasters is one of non-military threat that is very real in the territory of the United State of the Republic of Indonesia. Casualties, economic, social, environmental damage, and psychological impacts caused by the disaster are real conditions occur as a result of this non-military threat. The geographical position allows the threat of natural disasters due to the movement of tectonic plates and volcanic activity. This is a natural process always occurs in the cycle of life on earth. After an earthquake 9,1 magnitude followed a giant tsunami wave that devastated the city of Banda Aceh on December 26, 2004, an earthquake 6,5 magnitude occurred again which rocked the Pidie Jaya Regency area, Aceh Province on Wednesday, December 7, 2016, at 05.03.36 am. This research aims to study the management disaster during Pidie earthquake especially in emergency response. The results of this research are to make the earthquake in Pidie Jaya District in 2016 as a Lesson Learned for all parties, especially in Pidie Jaya District and in general, for all Indonesian people to form disaster-resilient communities who have awareness of the potential disasters that will be faced to contribute to the condition of National Security.
\end{abstract}

\section{Introduction}

The objective of the nation and the state of Indonesia is stated in the Preamble to the 1945 Constitution of the Republic of Indonesia, namely to protect the entire Indonesian nation and all spilled Indonesian blood and to advance the general welfare. Indirectly, to protect and achieve prosperity, national security is needed as a form of freedom for the state, society, and citizens from all forms of threats. Natural disasters are one of the threats that exist in Indonesia. This is supported by Indonesia's geographical position which is located on three earth plates, namely Indo-Australia, Eurasia, and the Pacific. The three earth plates are always moving and pressing against each other, causing an accumulation of collision energy which will eventually be released in the form of an earthquake [1]. This geographical position allows the threat of natural disasters due to tectonic plate movements and volcanic activity. Natural disasters that can be caused include earthquakes, tsunamis, and volcanic eruptions.

Indonesia is an active seismic area where during the years 1976-2006 there were 4,486 earthquakes with a magnitude of more than 6.0 on the Richter scale. Research by the Meteorology and Geophysics Agency (BMKG) since 1991-2009 there have been 27 destructive earthquakes and 13 earthquakes causing tsunamis. When averaged and rounded, Indonesia experiences earthquakes twice and tsunami once a year. In 2009 there was an earthquake that damaged Papua, Tasikmalaya, Padang and Ujung Kulon [2].

One of the provinces in Indonesia with quite intensive tectonic and volcanic activity is Aceh Province. One of the districts that experienced a devastating earthquake in 2016 is Pidie Jaya Regency. Pidie Jaya Regency is located at geographic coordinates $04^{\circ} 06^{\prime}-04^{\circ} 47^{\prime}$ North Latitude, $95^{\circ} 56$ '- $96^{\circ} 30^{\prime} \mathrm{E}$, with the northern borders directly adjacent to the Malacca Strait, to the east bordering Samalanga District, Bireun Regency. The south is directly adjacent to Tangse, Mane, and Geumpang Districts, Pidie Regency, in the west it is directly adjacent to Glumpang Tiga, Glumpang Baro, and Kembang Tanjong Districts, Pidie Regency. Pidie Jaya Regency has an area of ?? $1,162.84 \mathrm{Km}^{2}$ and a population of approximately 165,000 people [3]

Topographically, Pidie Jaya Regency is at an altitude of 0 masl to 2300 masl with a slope of land between 0 to $40 \%$. The area of Jangkabuya Subdistrict as a whole is a lowland area between 0 masl to 20 masl, Bandar Dua District is located at 10 masl s.dpl. 2300 masl while the Subdistricts of Ulim, Meurah Dua, Meureudu, Trienggadeng, Pante Raja, and Bandar Baru are located at 0 masl to 2,300 masl stretching from the Malacca Strait Coast to the Peak of Gunong Peuet Sagoe in the Bukit Barisan Cluster[4]. Overall, Pidie Jaya Regency is prone

* Corresponding author : najibrahman1106@gmail.com 
to flooding and erosion. From the slope classification, Pidie Jaya Regency is a highland area that has a slope class area of up to $40 \%$. After an earthquake measuring 9.1 magnitudes with a giant tsunami wave that devastated the city of Banda Aceh, Aceh Province on December 26, 2004. On Wednesday, December 7, 2016, at 05.03.036 WIB, an earthquake measuring 6.5 magnitudes occurred again which rocked the Pidie Regency area. Jaya, Aceh Province. This earthquake has resulted in significant casualties. Some victims suffered minor injuries to the point where the victim died. This earthquake also resulted in infrastructure damage in the form of buildings that were slightly damaged and collapsed [5]

The earthquake in Pidie Jaya was a natural event whose impact was not only visible on damage to building structures but also had an impact on the survival of the victims. According to data from BNPB, 102 victims died and 93 of them have been identified, and at least 650 people suffered serious and minor injuries. Not less than 85 thousand people packed the evacuation sites scattered in several sub-districts in the Pidie Jaya area. Nonmaterial impacts such as health, mental and emotional stability (trauma), livelihoods, education, and others are considered commensurate with or maybe more significant than the impact of damage to buildings. The value of damage that is material (tangible) may be calculated immediately and followed by rehabilitation and reconstruction immediately. However, non-material impacts require more special handling and take into account the phased aspects of the time. Therefore, it is necessary to further study post-earthquake rehabilitation and recovery programs that are suitable and provide longterm stability impacts on victims as a whole from economic, social, environmental, health, education, and other aspects [6].

The purpose of this research is to provide an overview and make the Earthquake incident in Pidie Jaya Regency a lesson for all Indonesian people to create a disasterresilient community to support National Security. The Earthquake Disaster that hit Pidie Jaya Regency in 2016 was an event that could be used as a learning for the entire community on how to process and analyze the disaster cycle that occurred and how to manage disasters more effectively and efficiently in the future.

\section{Method}

The methodology used in this research is a qualitative method with data collection techniques, namely interviews, observation, and document study. Qualitative research is a research procedure that produces descriptive data consisting of written and spoken words from sources [7]. Data collection techniques in this study were interviews, observation, and document study. In-depth interview techniques to obtain primary data from sources. Research sources came from related agencies, namely BPBD Pidie Jaya Regency, Syiah Kuala University Academics, Pidie Jaya District Social Service, NonGovernmental Organization (NGO) Disaster Risk Reduction Forum (FPRB) Pidie Jaya, Military District Command (KODIM) Pidie Jaya Regency, Pidie Jaya
District Health Office, Pidie Jaya Regency Public Works (PU) Office and Pidie Jaya Regency Environmental Service (DLH). Documentation techniques to collect secondary data so that it supports the data obtained in the interview technique.

The data analysis in this study used the Miles and Huberman model. Data analysis based on Miles and Huberman is data reduction, display data, and conclusion drawing and verification [8].

\section{Result and Discussion}

Pidie Jaya is a district located in Aceh province with the capital city of Meureudu. Pidie Jaya Regency consists of 8 districts, 34 Mukim, and 222 villages. The formation of Pidie Jaya Regency is based on Law Number 7 of 2007 on January 2, 2007 [9]. Based on its geographic location, Pidie Jaya Regency is depicted on the following map:

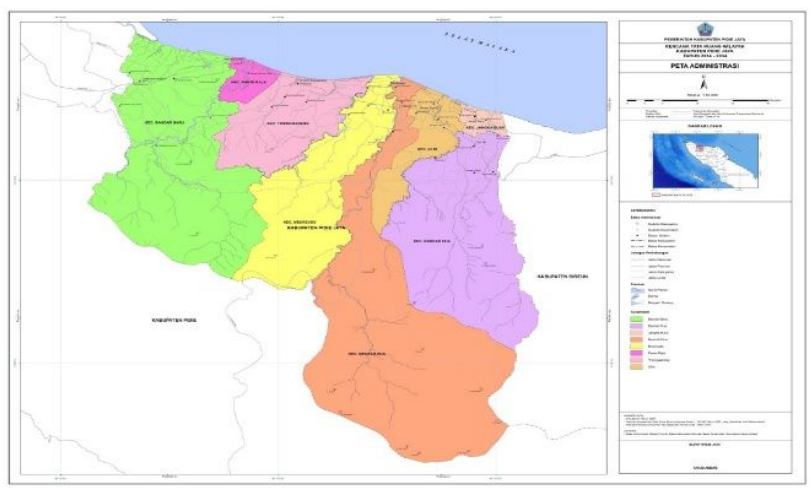

Fig. 1. Administrative Map of Pidie Jaya Regency [3]

Disaster Management Command System in the earthquake emergency response phase in Pidie Jaya district in 2016 in a disaster emergency, the Governor / Regent / Mayor appointed a disaster incidence commander at the suggestion of the Head of BPBD. Following the Regent's Decree Number 383 of 2016, the Deputy Regent was appointed as the Task Force for Emergency Response of the Pidie Jaya Earthquake. Furthermore, in the form of clusters (Sub Task Force) in disaster management such as the Refugee and Social Cluster, Field Cleaning, Health Clusters, and others [10].

Disaster Management Command System in the emergency response phase of the earthquake in Pidie Jaya district in 2016 in a disaster emergency, the Governor / Regent / Mayor appointed a disaster incident commander (Incidence Commander) at the suggestion of the Head of BPBD. Following the Regent's Decree Number 383 of 2016, the Deputy Regent was appointed as the Task Force for Emergency Response of the Pidie Jaya Earthquake. Furthermore, in the form of clusters (Sub Task Force) in disaster management such as the Refugee and Social Cluster, Field Cleaning, Health Clusters, and others.

Equations should be centered and should be numbered with the number on the right-hand side.

Table 1 Data on Damage and Loss of Pidie Jaya Disaster in 2016 [3] 


\begin{tabular}{|c|c|c|c|}
\hline No & Indicator & Description & Data Source \\
\hline 2 & Victim Died & 97 People & $\begin{array}{l}\text { Rehab and } \\
\text { Reconsent } \\
\text { Reaction Plan } \\
\text { for the 2017- } \\
2019 \\
\text { earthquake }\end{array}$ \\
\hline 3 & $\begin{array}{l}\text { Broken } \\
\text { House }\end{array}$ & $\begin{array}{l}\text { Several damaged } \\
\text { houses: } 3,205 \text { and } \\
\text { Moderately } \\
\text { damaged houses: } \\
\begin{array}{l}3,269 \\
\text { Total } \\
\text { Housing Unit }\end{array}\end{array}$ & $\begin{array}{l}\text { Rehab and } \\
\text { Reconsent } \\
\text { Reaction Plan } \\
\text { for the 2017- } \\
2019 \\
\text { earthquake }\end{array}$ \\
\hline 4 & $\begin{array}{l}\text { Material } \\
\text { Loss }\end{array}$ & $\begin{array}{l}\text { Rp. } \\
511,776,697,410\end{array}$ & $\begin{array}{l}\text { Rehab and } \\
\text { Reconsent } \\
\text { Reaction Plan } \\
\text { for the 2017- } \\
2019 \\
\text { earthquake }\end{array}$ \\
\hline & $\begin{array}{l}\text { Damage } \\
\text { Public } \\
\text { Facilities }\end{array}$ & $\begin{array}{l}\text { National Roads } \\
\text { and Bridges } \\
\text { Network, } \\
\text { Provincial Roads } \\
\text { and Bridges } \\
\text { Network, District } \\
\text { Roads and Bridges } \\
\text { Network, Clean } \\
\text { Water Network, } \\
\text { irrigation Network, } \\
\text { Dams, Beach } \\
\text { Protection } \\
\text { Buildings, Office } \\
\text { Buildings, } \\
\text { Hospitals, Public } \\
\text { Health Center, } \\
\text { Markets Facilities } \\
\text { and services }\end{array}$ & $\begin{array}{l}\text { Rehab and } \\
\text { Reconsent } \\
\text { Reaction Plan } \\
\text { for the 2017- } \\
2019 \\
\text { earthquake }\end{array}$ \\
\hline
\end{tabular}

Institutions involved in the First Emergency Response period include the Indonesian Ministry of Health (Directorate of Mental Health), PDSKJI Aceh (Psychiatrist at Tamiang Hospital, Biruen, North Aceh, Central Aceh, Mental Hospital, Aceh Jaya, Pidie), CMHN Trienggadeng, CMHN Banda Aceh, CMHN Pidie, Aceh Besar Health Office, Pidie Health Office, North Aceh Health Office, Directorate General P2P Ministry of Health, Aceh HIMPSI, IPK ACEH, East Kalimantan HIMPSI, IMHA, IPKJI, UIN Psychology Students, Unsyiah, P3KJB, PKM Bandar Dua, Aceh Police, PPNI Aceh, Puskesmas Keumala, Marzoeki Mahdi Hospital Bogor, RSJ Dr. Muwardi Solo, RSJ West Java, Soeharto Heerdjan Jakarta, PDSKJI Community Psychiatry and Crisis Center, Faculty of Psychology UI, UGM Disaster Team who went directly to the field [11].

Volunteers Helping the Pidie Jaya Earthquake, namely a volunteer team totaling 1,174 people, consisting of 186 government and non-government organizations including Dompet Dhuafa Aceh, Rumah Zakat, PKPU, KARINA, MDMC, WVI, nYEU, MSF, PMI, UGM Disaster Team with expertise as follows: (1) Specialist doctors: 58 people; (2) General practitioners: 241; (3) Psychiatrist / Psychologist: 50; (4) Paramedics: 408; (5) Other supporters: 417. Based on the origin of volunteers; (1) Countries: 2 Countries (Malaysia and Singapore); (2) Provinces: 13 Provinces (Aceh, North Sumatra, West Sumatra, Riau, Riau Islands, Bangka Belitung, DKI Jakarta, DIY, West Java, Central Java, East Java, East Kalimantan, South Sulawesi); (3) Regencies: 23 districts / cities in Aceh, and 16 from cities from other provinces (Medan City, Langkat, Binjai, Tebing Tinggi, Padang, Pekan Baru, Batam, Bangka Belitung, Jakarta, Bandung, Yogyakarta, Semarang, Solo, Surabaya, Bontang and Makassar); (4) Under the coordination of the Head of the Aceh Health Service; the Aceh Health Service SubCluster Team took turns to the location and the permanent team was the UPTD P2KK Team located at the Pidie Jaya Health Post. These teams are assigned and function to provide health services for disaster sites and assist Pidie Jaya District Health officers, who are victims of the disaster, either directly or indirectly [12]. The following is data on damage to health facilities at the time of the earthquake in Pidie Jaya Regency Pidie Jaya;

Table 2. Damage Data to Health Facilities [3]

\begin{tabular}{|c|l|c|c|c|c|}
\hline \multirow{2}{*}{ No } & \multirow{2}{*}{$\begin{array}{l}\text { Health } \\
\text { facility }\end{array}$} & \multicolumn{3}{|c|}{ Type Of Damage } & Total \\
\cline { 3 - 6 } & & Severe & Moderate & Light & \\
\hline 1 & $\begin{array}{l}\text { Public Health } \\
\text { Center }\end{array}$ & & 9 & & 9 \\
\hline 2 & Hospitals & 1 & & & 1 \\
\hline 3 & $\begin{array}{l}\text { Doctor's } \\
\text { Houses }\end{array}$ & & & 28 & 28 \\
\hline 4 & Post & 3 & 10 & 4 & 17 \\
\hline 5 & Post-Dpctor's & 14 & 37 & 29 & 80 \\
\hline 6 & $\begin{array}{l}\text { Public Health } \\
\text { Office }\end{array}$ & & & 1 & 1 \\
\hline 7 & $\begin{array}{l}\text { Pharmacy } \\
\text { Warehouses }\end{array}$ & & & 1 & 1 \\
\hline \multicolumn{7}{|l}{ Total } & 18 & 56 & 63 & 137 \\
\hline
\end{tabular}

On December 7, 2016, an earthquake disaster occurred in Pidie Jaya and resulted in achievements in the following stages: Emergency Response 7-20, Rehabilitation-Reconstruction Action Plan 2017-2019, Presidential Instruction for Acceleration of Rehabilitation-Reconstruction Action Plan, Groundbreaking of earthquake victims' houses on April 21, 2018, in 2019 the physical recovery has been completed but non-physical is still unknown. In Pidie Jaya the delay in recovery was caused by the impact of the disaster on the fiscal, namely revenues and expenditures. One of the factors of socio-economic recovery is always being late because disaster recovery actors do not understand the character of the relationship for each period. Different stages of disaster management require different resources [13].

Based on the results of interviews and direct in-depth studies with the Head of the Public Works and People's Permahan through a zoom meeting that the Public Works and Public Housing (PUPR) Office of Pidie Jaya Regency in carrying out the disaster management for the 2016 Pidie Jaya earthquake experienced many obstacles including heavy equipment. Regarding heavy equipment, the local government has 4 heavy equipment to clean debris after the earthquake. The Public Works and Public Housing 
(PUPR) Office also requested assistance from academics to record damage and conduct rapid assessments of the earthquake disaster in Pidie Jaya [14].

The main points of post-disaster rehabilitation and reconstruction policies for the earthquake in Pidie Jaya, Pidie, and Bireuen: Facilities for building communities, principles of sustainable development, and disaster risk reduction, good governance and prioritizing the aspirations of disaster-affected communities, participatory approaches under local cultural characteristics, Earthquake-friendly housing technical standards, the openness of information, accountable distribution of funds and accountability, effective coordination and cooperation between parties across sectors, Considering the impact of damage and budget availability, the post-disaster rehabilitation, and reconstruction plan will cover the 2016 - 2018 fiscal year [15].

Problems that arise during the Emergency Period, such as the evacuation of bodies, looting, mass graves, misappropriation of aid, education, and opening of markets. Problems that arise during Rehabilitation and Reconstruction, such as relocation, land conflicts, uncooperative government officials, and rogue contractors. Good restoration is highly recommended for an indirect recovery stage from relocation to permanent buildings. There needs to be a smooth stage from emergency tents, shelters, to the construction of permanent houses. It is hoped that problems that arise during the emergency and rehabilitation and reconstruction period can be handled perfectly and create a Build Back Better. Physical recovery is easier, but socioeconomic recovery will take longer because it requires a more comprehensive approach. Not only relying on the government, but universities with available resources have an important role to play in dealing with disasters.

There are 5 (five) focuses on the integration of spatial planning with disaster risk reduction, namely: (1). Integration of disaster risk studies into urban planning including special attention to settlements that are prone to disasters; (2) Prioritizing disaster risk considerations for vital infrastructure development activities; (3) Development and use of monitoring tools to measure aspects of risk reduction obtained on a spatial planning policy; (4) Integration of disaster risk studies into rural development planning, especially in mountainous and coastal areas; (5) Revision or development of building codes and reconstruction and rehabilitation practices at the national and local levels [16].

The pattern of spatial use in protected areas is aimed at realizing environmental sustainability, increasing the carrying capacity of the environment, and maintaining the balance of the ecosystem between areas to support the sustainable development process. Based on these considerations, the protected area utilization plan is: (1). Directing the function of the protected area which includes plans for spatial use in areas that protect the areas under it, nature reserves, local protected areas, and disaster areas; (2). Maintain water catchment areas or areas that have a hydrological function to ensure the availability of water sources; (3). Controlling the use of space outside the forest area so that it continues to function in protection [17].

The development of the spatial use area in the cultivation area aims to maintain the quality of the carrying capacity of the Pidie Jaya district in the planning area to create jobs, create harmony with the spatial structure plan being developed. The cultivation area includes residential areas, food crop agricultural areas, annual crops/plantations, livestock areas, fisheries areas, and tourism areas.

The development of disaster-prone areas is an effort to maintain balance against natural conditions that are prone to change. These changes occur due to floods, landslides, abrasion and earthquakes, and other changes. These disaster-prone areas must be protected from human settlements through various plans, namely forming borders and green open areas to minimize the impact of changes in these conditions. Disaster-prone areas are coastal areas of the sea and river banks (DAS).

The Concept of Flood Disaster Prone Area Arrangement, Includes: (1). Arrangement of Upstream Watershed Areas; (2). Management of Downstream Watershed Areas. The concept of Earthquake Disaster Disaster Management Arrangement includes: (1). Recommendations for RTH for Multi-functional City Disaster Evacuation Sites; (2) Disaster Evacuation Route System; (3). Evaluation of the New Development Plan at KRB Earthquake; (4). Space Allocation Alternative and Space Utilization Intensity Limitation; (5). Concept of Building Period; (6). Building Code in Earthquake Prone Areas [18].

The concept of Tsunami Disaster Prone Area Arrangement includes; (a). Structural Mitigation Development; (b) Management of Mangrove Areas; (c) Conservation of Coral Reefs. The concept of Landslide Hazard Area Arrangement, including; (1) Development of Structural Mitigation; (2) Management and Control of Protected Forest Utilization and Forest and Land Rehabilitation in Landslide KRB; (3) Soil and Water Conservation.

Disaster Risk Reduction in Pidie Jaya Regency is carried out by considering sustainability aspects and participation of all parties. This effort is carried out with a strong commitment by prioritizing actions that must be prioritized. Disaster Mitigation is carried out to reduce the risks and impacts caused by disasters on communities living in disaster-prone areas through: (a). Planning and implementation of spatial planning based on disaster risk analysis; (b) Regulation, development, infrastructure development, and building layout; (c). Providing conventional and modern education, training, and counseling.

The success of disaster risk reduction efforts in an area cannot be separated from the quality of the environment and enforcement of spatial planning, which can be seen from: (1) Availability of information on disaster-prone areas/areas; (2). The implementation of the licensing process for development activities is guided by the Disaster-based District / District Spatial Plan and the fulfillment of environmental quality. Control and enforcement of disaster-resistant building structures, including: (1). Supervision and control of land use in areas 
that are vulnerable to disasters; (2). Availability of a disaster evacuation route/space; (3). Increase public awareness of maintaining good spatial and environmental quality.

The following is an overview of disaster-prone areas in the Pidie Jaya district:

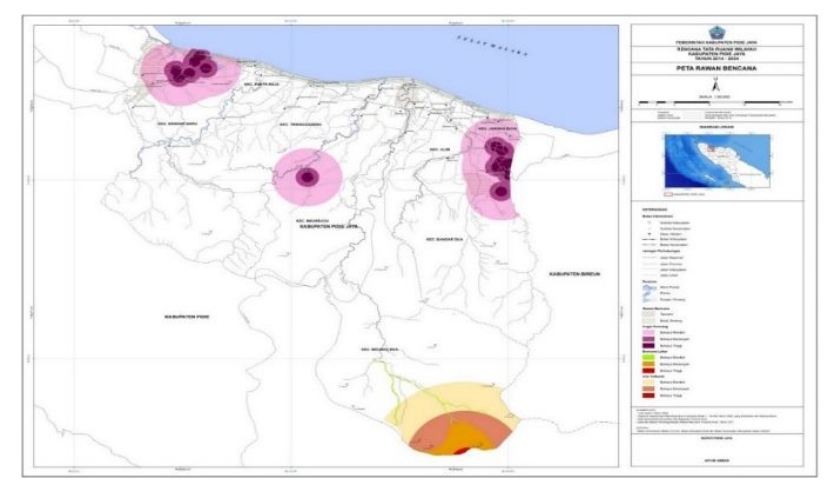

Fig. 2. Map of Disaster Hazard in Pidie Jaya Regency [3]

Based on Fig. 2, a tabulation can be made about the sub-districts in Pidie Jaya Regency which have the highest number of natural disaster threats which csan be seen in Table 3. It can be seen that Meureudu, Meurah Dua, and Bandar Baru sub-districts have three natural disaster threats and Bandar dua sub-districts which have two threats and the rest of each region has one threat of disaster, namely Tsunami.

After the 2004 Aceh earthquake and tsunami, parts of Aceh, namely Pidie Jaya district, experienced another devastating disaster in 2016, namely an earthquake. This incident gave psychological trauma to all members of the community. Many residents lost their parents, children, siblings, friends, and friends. This incident also resulted in the loss of property, environmental damage, and loss of hope for the people of Pidie Jaya Regency. Therefore the importance of vigilance and preparedness of all components of society and the nation is facing the conditions of a disaster that will occur and how to reduce the impact of the resulting risks to the minimum. The lesson (Lesson Learn) regarding the Pidie Jaya earthquake has made the community even more resilient to disasters in the future. The emergence of an awareness of disasters has made people work hand in hand to face and build disaster preparedness. The formation of disaster-resilient villages, disaster prepared schools is a description of awareness and evidence of community learning about disasters that occur to form disaster-resilient communities that will contribute to National Security [19].

\section{Conclusion And Suggestion}

Lessons learned from the 2016 Earthquake disaster in Pidie Jaya Regency were: (a). Initiatives must be initiated from higher education institutions because they have the resources to make initial efforts; (b). Provide recommendations to the government regarding the results of rapid assessments; (c). Various Stakeholders can always accompany the results of the rapid assessment up to the rehabilitation and reconstruction stage; (d). Disaster evacuation management must be faster and more systematic; (e) Providing more comfortable and attractive evacuation tents for earthquake victims such as disaster victims in Japan; (f). The 4000 Pidie Jaya refugees lacked facilities such as public kitchens, only 2 (two) were provided so that the distribution of consumption was often late. The bathroom which was only provided with 4 pieces caused illness in the evacuation victims. In the event of a disaster, there are always lessons to be learned for system improvement and management of what will be faced in the future.

Quick response, quick assessments, and good coordination must be carried out immediately because an action plan will emerge. Quick assessment from the socioeconomic aspect: (a). Coordination between institutions and to the community: establishment of posts, contingency plans, consolidation at the provincial level; (b). Logistics channeling mechanism to the community: distribution points must be recorded by involving students and other components of society; (c). The decision to evacuate the community: there needs to be coordination and an appeal to rely on the community to evacuate themselves; (d). Capacity for the number of refugees and production capacity: mobilization must be accompanied by mobilization of resources; (e). Health and hospital service aspects: services must always be ready, either from hospital facilities or from the trauma-healing aspect of post-disaster. Processes, fast and precise responses are the keys to success in handling the earthquake disaster that occurred in the Pidie Jaya district. Careful coordination and good preparedness will form a community resilient to disasters and will ultimately contribute to a stable condition of National Security.

\section{References}

1 Center for Volcanology and Geological Mitigation., Earthquake and Tsunami. Geological Agency, Ministry of Energy and Mineral Resources (2015).

2 Sunarjo, M. T. G., S. Pribadi, Popular Edition Earthquakes. Meteorology Climatology and Geophysics Council (2012).

3 BPBD of Piedie Jaya Regency, General Condition of Pidie Jaya Regency (2020).

4 Akbar, K. N., Earthquake Geographic Information System Damaged In Indonesia In The Center of Vulanology And Web-Based Geological Disaster Mitigation. (2011).

5 S. Maarif, R. Parmono, R. A. Kinseng, E. Sunarti, Contestation of Knowledge and Meaning of Natural Disaster Threats: A Case Study of Mount Merapi Disaster Threats. Journal of Dialogue and Disaster Management, 3 (1), 1-13, (2012).

6 D. Hidayati, Community preparedness: A new paradigm for natural disaster management. Journal of Indonesian Population, 3 (1), 69-84, (2008).

7 L. J. Moleong, Qualitative Research Methodology. PT. Rosdakarya youth, (2010). 
8 Sugiyono, Quantitative Approach Business Research Methods, Qualitative and $R \& D$. Alfabeta (Bandung, 2010).

9 National Center for Earthquake Studies Team, Pidie Jaya Earthquake Study in Aceh Province, Indonesia, December, $7^{\text {th }} 2016$ (M6.5). Research and Development Center for Housing and Settlements Bdan Research and Development Ministry of Public Works and Public Housing (2017).

10 M. Fadri, M. Zuhri, Effectiveness of Regional Disaster Management Agency Functions in Earthquake Management in Pidie Jaya Regency. Student Scientific Journal in the Field of State Law, 2 (2), 336-346 (2018).

11 K. Wikantika, P. A. D. Prastiwi, R. Vitriana, A. B. Harto, Identification of Post-Earthquake Damage Using the Object-Based Image Analyzer (OBIA) Method (Case Study: Pidie Jaya, Aceh) (2017).

12 Pidie Jaya District Health Office, Health Sector Condition Data (2020).

13 Q. Qadariah, A. V. Simanjuntak, M. Umar, Analysis of Focal Mechanisms Using Waveform Inversion; Case Study of Pidie Jaya Earthquake on december $7^{\text {th }}$
2016. Journal of Aceh Physics Society, 7 (3), 127 132, (2018).

14 A. Rahma, Implementing disaster risk reduction (DRR) programs through formal education. Journal of VARIDIKA, 30 (1), 1-11, (2018).

15 H. Susetyo, S. H., L, S. I, M., Towards a comprehensive security paradigm with a human security perspective in Indonesia's national security policy, Esa Unggul University (2008).

16 S. Mukhtar, National security: between theory and practice in indonesia 1. Sociae Polites, 127-137, (2017).

17 K. Anggoro, National security, national defense, and public order. In Seminar on National Law Development VIII. Denpasar: National Law Development Agency, Ministry of Justice and Human Rights of the Republic of Indonesia (2003).

18 K. Munadi, D. Yuliansyah, Multi Threat Information System for Natural Disasters in Aceh. In the National Informatics Seminar (2011).

19 B. Darmono, Indonesian National Security System and Concept. National Journal of Resilience, 15 (1), $1-42,(2010)$ 